[13] Mizhnarodni standarty profesiynoyi praktyky vnutrishnogo audytu [International Standards for the Professional Practice of Internal Auditing] (2017). Kyiv: The Institute of Internal Auditors of Ukraine, The Institute of Internal Auditors, 36. Available at: https://www.iia.org.ua/?page_id=189

[14] Pysmenna, M. S. (2011). Vnutrishnii audyt v bankivskii systemi [Internal Audit in the Banking System]. Odessa, 265.

[15] Osnovni polozhennya mizhnarodnoyi profesiynoyi praktyky vnutrishnogo audytu [The main provisions of international professional practice of internal auditing. Practical advice] (2014). Kyiv: The Institute of Internal Auditors, 160.

[16] Pro organizatsiyu vnutrishnogo audytu v bankah Ukrayiny [The organization of internal audit in banks of Ukraine] (2016). NBU No. 311. 10.05.2016. Available at: https://zakon.rada.gov.ua/laws/show/v0311500-16

[17] Omelyanchuk, T. (2014). Zastosuvannia analitychnyh protsedur v auditi finansovogo stanu pidpryiemstv restorannogo gospodarstva [The use of analytical procedures in auditing the financial condition of the restaurant business]. Galician economic journal, 44 (1), 146-153.

\title{
ESTIMATION OF THE OVERALL TAX BURDEN ON THE ECONOMY IN UKRAINE
}

\author{
Valentyna Martynenko \\ Educational and Scientific Institute of Accounting, Analysis and Audit \\ University of State Fiscal Service of Ukraine \\ 31 Universytetska str., Irpin, Kyiv Region, Ukraine, 08201 \\ martynenkovv@ukr.net
}

\begin{abstract}
The estimation of the tax burden is important, since, on the one hand, its results reflect the tax system efficiency, and, on the other hands, the level of income redistribution in the national economy. The estimation of the general tax burden level on the national economy of Ukraine should be realized through the development of forecast scenarios, based on economic and mathematical modelling. The economists have not yet sufficiently worked out the problems of the predictive assessment of the tax system efficiency through the introduction of a scenario approach, economic-mathematical modelling and extrapolation of dynamics series. It is necessary to evaluate and to develop scenarios for forecasting the level of the overall tax burden on the national economy of Ukraine. The modelling of the influence of GDP dynamics on the volume of tax revenues and a unified social tax is implemented. The method of calculating the level of the overall tax burden on the national economy is proposed. The scenarios for forecasting the total tax burden on the Ukrainian economy have been developed. It is proved that in Ukraine, by the end of 2017, one third of the revenues in the national economy is redistributed through the fiscal system, while in 2004 the tax burden made only a quarter of GDP. Thus, it is established, that over the next 5 years, the overall tax burden on the national economy will increase (growth may range from +0.9 to $+4 \%$ ).
\end{abstract}

Keywords: direct taxation, indirect taxation, unified social tax, national economy, GDP dynamics.

DOI: $10.21303 / 2504-5571.2019 .00947$

\section{Introduction}

In the context of macroeconomic instability and the debt problem aggravation, the estimation of tax burden becomes of particular importance, since, on the one hand, its results reflect the efficiency of the tax system, and, on the other hand, the level of income redistribution in the national economy. Also, the tax burden must fulfill the stimulating function, based on the effect of setting such tax rates, under which the business will receive more benefits from legal status than when doing the underground work.

To study the effectiveness of the tax system of Ukraine, it is necessary to estimate the level of the total tax burden on the national economy by developing forecast scenarios, based on the 
mathematical dependencies of tax revenues to the consolidated budget of Ukraine and the paid unified social tax from GDP dynamics at current prices.

The basic methodological foundations for estimating the overall tax burden both for the national economy as a whole and for individual economic entities in particular are described in the scientific papers of many scholars. For example, A. Atkinson (1979) investigated the horizontal equity and the distribution of the tax burden [1]. B. Reed and C. Rogers (2006) analyzed the empirical relationships between changes in Tax Burden and changes in tax policies from 1987 to 2000, using states' forecasts of revenue impacts of new tax legislation [2]. Kaplow L. (2010) focused in his book on established results from the standard optimal tax model, with its assumptions of fully optimizing consumers under complete information, no costs of tax administration, and no inefficient political processes [3]. C. Spengel, W. Li, W. Zinn and K. Finke (2011) provide a comparative analysis of the corporate tax regimes in four important Asian countries, namely China, India, Japan and Singapore [4]. A. Tiwari (2012) used the frequency domain approach to investigate the short- and long-run Granger-causality from different tax burden measures to GDP for the period 1947:1-2009:3 for the USA [5]. The collective monograph by V. Bashko, T. Koschuk, O. Ozerchuk, Ya. Petrakov, A. Sokolovska (ed.), O. Tymchenko and T. Yefymenko (ed.), (2014) is devoted to a comprehensive analysis of the tax burden on the economy, factors of production and individual economic agents [6]. The author also began to investigate this problem in previous articles $[7,8]$.

Ideas for estimating the level of tax burden on the economy, both in developed countries and in developing countries, in particular in Ukraine, do not lose their relevance today. The economists have not yet sufficiently worked out the problems of the predictive assessment of the tax system efficiency through the introduction of a scenario approach, economic-mathematical modeling and extrapolation of dynamics series.

\section{Aim of Research}

The main objective of the study is to estimate and forecast the level of the total tax burden on the national economy in Ukraine.

\section{Materials and Methods}

The general tax burden (in some scientific sources, the term "tax load" is used) on the national economy is an indicator that gives a quantitative characteristic of the state system and can be used both for assessing trends of its development in the dynamics for the researched period and for the international comparisons. Also, this indicator can serve as an income redistribution indicator in the national economy.

We will analyze the dynamics of tax revenues, revenues of the consolidated budget of Ukraine and the GDP at current prices (Table 1).

The data, given in Table 1, make it clear that the total volume of tax revenues to the budget for the years 2004-2017 increased by 12.9 times. As a result, the consolidated budget revenues increased by 11.5 times. At the same time, the amount of the unified social tax increased only by 5.6 times, which may indicate a much lower growth rate of individuals' income, compared with other tax bases. During the above mentioned period, GDP at current prices increased by 8.3 times; whether, the place and role of the tax burden remains unclear - it is a factor that increases (stimulates) or slows (prevents) the economic growth.

The overall tax burden on the national economy (TB) is understood as the percentage of the total amount of all tax revenues to the budget and the unified social tax $\left(\mathrm{T}_{\mathrm{i}}\right)$ to the GDP at current prices (GDP):

$$
\mathrm{TB}=\left(\sum_{\mathrm{i}=1}^{\mathrm{n}} \mathrm{T}_{\mathrm{i}} / \mathrm{GDP}\right) \cdot 100 \%,
$$

where $0 \leq \mathrm{TB} \leq 100 \%$. 
Table 1

Development indicators of the national economy of Ukraine

\begin{tabular}{|c|c|c|c|c|}
\hline \multirow{2}{*}{ Year } & \multicolumn{4}{|c|}{ Indicator values arranged by the years, million UAH: } \\
\hline & Tax revenues & Unified social tax & Consolidated Budget Revenues & GDP at current prices \\
\hline 2004 & 64280 & 28182 & 88300 & 357544 \\
\hline 2005 & 100748 & 41591 & 131312 & 457325 \\
\hline 2006 & 131106 & 54293 & 168626 & 565018 \\
\hline 2007 & 167949 & 75534 & 216050 & 751106 \\
\hline 2008 & 235680 & 101951 & 291163 & 990819 \\
\hline 2009 & 209789 & 99821 & 280217 & 947042 \\
\hline 2010 & 236901 & 119343 & 304851 & 1120585 \\
\hline 2011 & 323991 & 139056 & 387853 & 1349178 \\
\hline 2012 & 347986 & 157980 & 432944 & 1459096 \\
\hline 2013 & 341165 & 166864 & 429986 & 1522657 \\
\hline 2014 & 355428 & 165923 & 443983 & 1586915 \\
\hline 2015 & 507636 & 169874 & 652031 & 1988544 \\
\hline 2016 & 650782 & 111707 & 782748 & 2385367 \\
\hline 2017 & 828159 & 158910 & 1016788 & 2983882 \\
\hline $\begin{array}{l}\text { Changes in 2017, } \\
\text { compared to } \\
2004(+/-)\end{array}$ & +763879 & +130728 & +928488 & +2626338 \\
\hline
\end{tabular}

Source: prepared by the author according to the data given in [9-11]

\section{Results and Discussion}

The tax process is a mechanism for redistributing income in the national economy and its key role is to ensure the fulfilment of state functions. It is obvious that the dynamics of state income in the form of tax revenues directly depends on the trends of GDP changes, which reflect the national economy development (Fig. 1).

The data in Fig. 1 show that there is a direct correlation between the dynamics of GDP at current prices and the amounts of consolidated budget revenues, tax revenues and a unified social tax, formalized by the power function, where:

- the GDP growth by $1 \%$ per year leads to an increase in the consolidated budget revenues by $1.1 \%$ with $99.3 \%$ confidence;

- with $99.2 \%$ confidence the annual amount of tax revenues to the budget increases by $1.14 \%$, with the GDP growth by $1 \%$ per year;

- the annual amount of a unified social tax may increase by $0.83 \%$ with $81.4 \%$ confidence, when the GDP at current prices rises by $1 \%$ per year.

In order to estimate the overall tax burden on the Ukrainian economy, we will first analyze the dynamics of its components:

- direct taxation burden - the correlation between the budget revenues from direct taxes and the GDP at current prices;

- the indirect taxation burden - the correlation between the budget revenues from indirect taxes and the GDP at current prices;

- the unified social tax burden - the correlation between revenues from the unified social tax to and the GDP at current prices (Fig. 2).

From the data of Fig. 2 it is evident that during the investigated period, the structure of the tax burden on the national economy has undergone significant transformations. Thus, the total tax burden on the national economy in 2017, as compared with 2004, increased by $7.2 \%$, including the share of indirect taxation burden, increased by $8.3 \%$, the share of direct taxation, increased by $1.5 \%$, and the burden of a unified social tax, decreased by $2.6 \%$. It is worth noting that in 2004, the impact 
of direct taxation was prevailing at $10.8 \%$ and the impact of the unified social tax at $7.9 \%$ (total $18.7 \%$ ) against $7.1 \%$ of indirect taxation. Instead, in 2017, the share of indirect taxation in the tax burden on the economy grew every year and reached a record number of $15.4 \%$ against the record number of $12.4 \%$ of the direct taxation share and low $5.3 \%$ of the unified social tax (total $17.7 \%$ ).

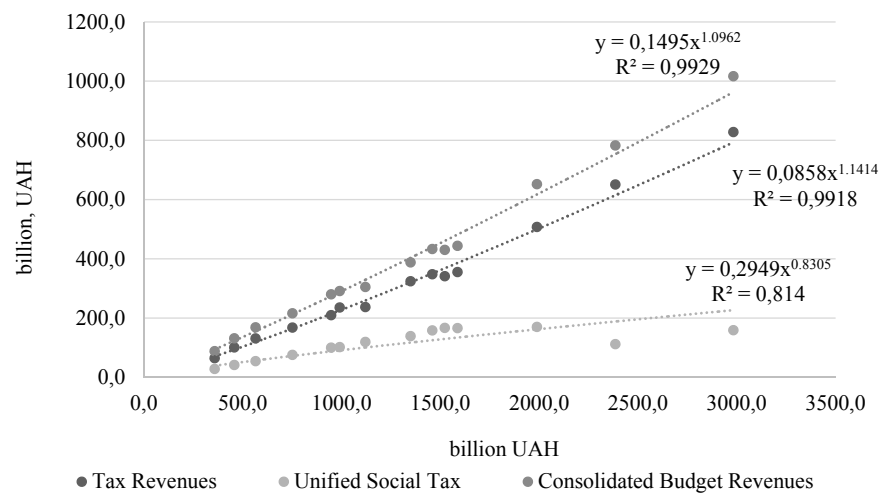

Fig. 1. Influence of GDP dynamics on consolidated budget revenues, tax revenues and a unified social tax, billion UAH

Source: prepared and calculated according to the data given in Table 1

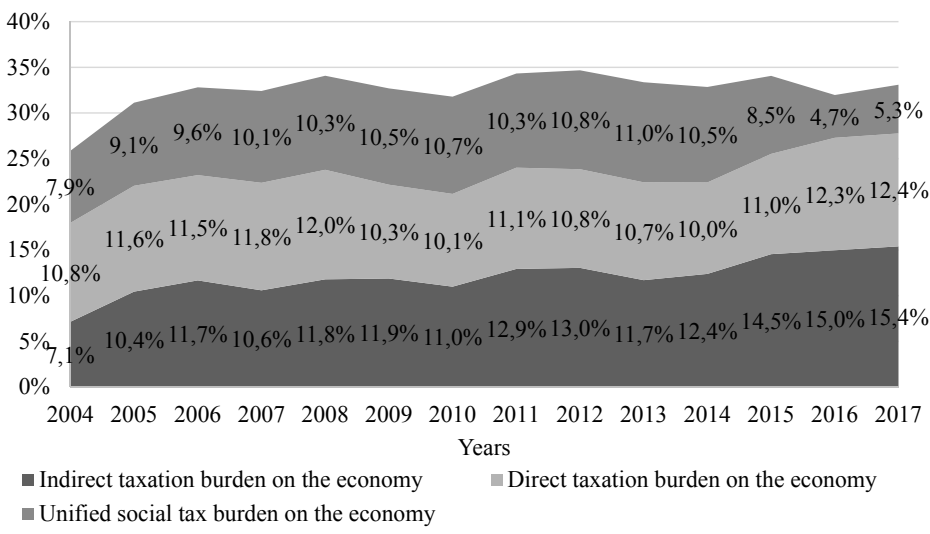

Fig. 2. Dynamics of the structure of tax burden on the national economy of Ukraine in 2004-2017 Source: prepared and calculated according to the data given in [9-11]

Such significant changes happened first of all due to the introduction of the unified social tax rate in the amount of $22 \%$, the double increase of the minimum wage (UAH 3200), starting from the beginning of 2017, as well as the forced payment of VAT by the agricultural producers at the beginning of 2016. Another factor in increasing the burden of indirect taxation on the economy is the escalation of inflation (148.7 \% in 2015, $113.0 \%$ in 2016 and $114.4 \%$ in 2017 [12]), which led to a general rise in commodity prices, as well as prices for works and services.

The total tax burden increased from $25.9 \%$ of GDP or 92.5 billion UAH (absolute minimum of the analyzed period) in 2004 to $33.1 \%$ of GDP or UAH 987.1 billion in 2017, reaching a maximum of $34.7 \%$ GDP in 2012. It may be concluded that about one third of the nominal GDP of Ukraine is redistributed in the national economy through the fiscal system.

At the end of the study, using the formulas given in Fig. 1, and the extrapolation method of dynamics series (Fig. 3), a scenario analysis was carried out in forecasting the total tax burden on the economy, the which results are shown in Table 2.

From the data given in Table 2, it can be seen, that according to the pessimistic scenario, in the next 5 years the level of the total tax burden on the Ukrainian economy may increase by $0.9 \%$, reaching $34 \%$ by the end of 2022 . According to a realistic scenario, the researched indi- 
cator could reach $35.3 \%$, increasing by $2.2 \%$, compared with 2017 . According to the optimistic scenario, $-37.1 \%$ and $+4 \%$ respectively.

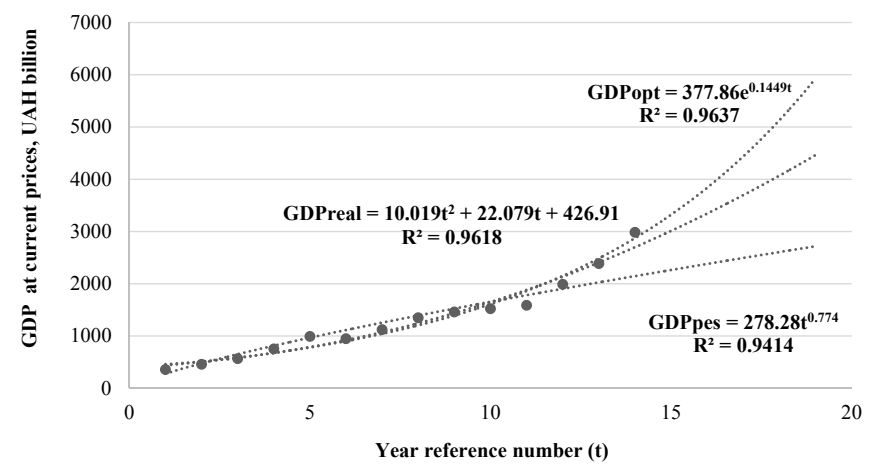

Fig. 3. Extrapolation of a GDP dynamics series at current prices, UAH billion Source: author's own calculations according to the data given in the Table 1

Table 2

Forecast scenarios of the total tax burden on the Ukrainian economy

\begin{tabular}{|c|c|c|c|}
\hline \multirow{2}{*}{ Years } & \multicolumn{3}{|c|}{ Indicator Forecast Scenarios } \\
\hline & Pessimistic & Realistic & Optimistic \\
\hline \multicolumn{4}{|c|}{ 1. Total tax revenues to the consolidated budget of Ukraine, billion UAH } \\
\hline 2018 & 578.93 & 802.26 & 1947.47 \\
\hline 2019 & 612.90 & 904.15 & 2096.35 \\
\hline 2020 & 646.62 & 1013.75 & 2246.54 \\
\hline 2021 & 680.11 & 1131.20 & 2398.00 \\
\hline 2022 & 713.39 & 1256.61 & 2550.64 \\
\hline \multicolumn{4}{|c|}{ 2. Amount of unified social tax, billion UAH } \\
\hline 2018 & 180.23 & 228.51 & 435.67 \\
\hline 2019 & 187.86 & 249.28 & 459.66 \\
\hline 2020 & 195.33 & 270.92 & 483.39 \\
\hline 2021 & 202.64 & 293.42 & 506.89 \\
\hline 2022 & 209.80 & 316.75 & 530.17 \\
\hline \multicolumn{4}{|c|}{ 3. Overall tax burden of the national economy, $\%$} \\
\hline 2018 & 33.54 & 34.22 & 36.37 \\
\hline 2019 & 33.65 & 34.48 & 36.57 \\
\hline 2020 & 33.76 & 34.74 & 36.77 \\
\hline 2021 & 33.87 & 35.00 & 36.95 \\
\hline 2022 & 33.97 & 35.25 & 37.12 \\
\hline
\end{tabular}

Source: author's own calculations according to the data shown in Fig. 1, 4

The method of extrapolation, which is used in forecasting the total tax burden on the economy, is based on the assumption that the revealed tendencies of GDP dynamics in actual prices will remain in the forecast period. Therefore, the relationship equation, whose graph is called the trend line, remains unchanged. So, Fig. 3 shows 3 equations of trends, the approximation level of which $\mathrm{R}^{2}>0.9$, which indicates a high level of confidence in the formalization of the current trend in the development of GDP in actual prices for 2004-2017. The author proposed to extrapolate the value of the studied indicator for 5 forecast years in advance, using the above equations of trends. The base is the quadratic trend equation, the calculated forecast values for which will form a realistic scenario for forecasting GDP in actual prices (GDPreal). 
Also an important aspect of the extrapolation technique of a number of dynamics is the establishment of confidence intervals. They expand the boundaries of the forecast by an area into which the forecast values of GDP in actual prices are likely to fall. These are points with corresponding coordinates, where the independent variable will be the sequence number of the forecast year. In this case, the upper confidence interval is formed by the equation of the exponential function (Fig. 3). It is a limitation of the potential maximum values of GDP in actual prices with the best contribution of growth factors, that is, it can correspond to an optimistic forecast scenario (GDPopt). The lower confidence interval is constructed according to the equation of a power function (Fig. 3). It is a limitation of the potentially smallest values of GDP at actual prices, subject to the bad influence of factors, leading to a decline, that is, it can correspond to a pessimistic forecast scenario (GDPpes). The author considers the disadvantage of the study to be the neglect of the influence of other factors, except for the time factor and the invariability of the indicator development trend. This will be taken into account in further research.

Analyzing the results of the assessment of the level of the total tax burden on the national economy of Ukraine, it was proved, that in 2004 the share of all tax revenues to the budget and the single social contribution to obligatory state social insurance amounted to one fourth of GDP at actual prices. In 2016, the total tax burden on the national economy made up the third part of GDP. The characterized negative dynamics was provided by increasing the burden of indirect taxation, which amounted to $15.4 \%$ of GDP at the end of 2017 against $7.1 \%$ of 2004 , while the share of direct taxation in the total load decreased by $1 \%$. Using the method of extrapolation of time series, a scenario analysis was implemented in predicting the total tax burden on the economy. The author substantiates that over the next 5 years, while the existing trends in GDP dynamics in actual prices, tax revenues to the budget and the unified social contribution remain unchanged, the total tax burden on the national economy will increase (the increase may be from 0.9 to $+4 \%$ ).

It should be noted that in the course of the study, similar results, obtained by the author, were not found in other works. But in the "Paying Taxes" ranking of tax system favorableness [13], the total tax and contribution rate is calculated as the ratio of all taxes and contributions to be paid by the conventional standard medium-sized company (micro level), taking into account the existing benefits (corporate income tax, social contributions and labor taxes, paid by employers, property taxes, turnover taxes, local taxes and fees, taxes on vehicles, etc.) to the commercial profit of a conventional company. At the same time, the value added tax (VAT) and similar taxes such as sales tax or goods and service tax, as well as personal income tax, are not included in the calculation of the total rate of taxes and contributions, as they are not paid at the expense of the company [8, 14]. Fig. 4 compares the results obtained (Fig. 2) with the results of the unique report by PwC and the World Bank Group.

Fig. 4 shows that during 2005-2017 there was a consistent decrease in the tax burden on business (an average of $-3.0 \%$ per year) and an increase in the tax burden on the national economy (an average of $+0.5 \%$ per year). At the same time, the level of tax burden on business for the investigation period decreased by $18.6 \%$, while the tax burden on the national economy increased by $2 \%$.

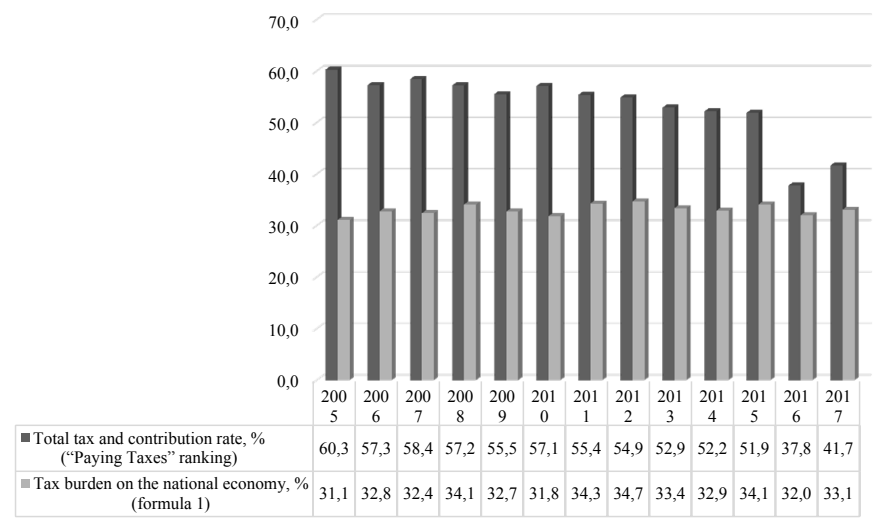

Fig. 4. Comparison of tax burden on macro and micro levels in Ukraine during 2005-2017 Source: prepared and calculated according to the data given in [9-11, 14-15] 


\section{Conclusions}

Thus, the results of estimation of the general tax burden level of the national economy of Ukraine make it possible to draw the following conclusions:

1) by the end of 2017, one third of the revenues in the national economy is redistributed through the fiscal system, while in 2004, the tax burden was only the fourth part of GDP at current prices;

2) the overall tax burden on the national economy is proposed as the percentage of the total amount of all tax revenues to the budget and the unified social tax to the GDP at current prices;

3) based on the results of forecasting, it is proved, that over the next 5 years, the overall tax burden of the Ukrainian national economy will increase.

\section{References}

[1] Atkinson, A. B. (1979). Horizontal equity and the distribution of the tax burden. The Economics of Taxation. Washington: Brookings, 3-18.

[2] Reed, W. R., Rogers, C. L. (2006). Tax Burden and the Mismeasurement of State Tax Policy. Public Finance Review, 34 (4), 404-426. doi: http://doi.org/10.1177/1091142106288406

[3] Kaplow, L. (2010). The theory of taxation and public economics. New Jersey: Princeton University Press. doi: http://doi.org/ $10.1515 / 9781400839223$

[4] Spengel, C., Li, W., Zinn, B., Finke, K. (2011). The computation and comparison of the effective tax burden in four Asian countries. Hitotsubashi Journal of Economics, 52 (1), 13-39.

[5] Tiwari, A. K. (2012). Tax burden and GDP: evidence from frequency Doman approach for the USA. Economics Bulletin, 32 (1), 147-159.

[6] Yefymenko, T. I., Sokolovska, A. M., Ozerchuk, O. V.; Yefymenko, T. I., Sokolovska, A. M. (Eds.) (2013). Dynamika podatkovoho navantazhennia v Ukraini v konteksti realizatsii podatkovoi reformy [Dynamics of tax burden in Ukraine in the context of tax reform implementation]. Kyiv: DNNU “Akademiia finansovoho upravlinnia", 492.

[7] Martynenko, V. V. (2018). On the problem of tax system optimization in Ukraine. Scientific Bulletin of Polissia, 1 (2 (14)), 129-134. doi: http://doi.org/10.25140/2410-9576-2018-2-2(14)-129-134

[8] Martynenko, V. (2019). Assessment of favourableness for the tax system of ukraine in the international context. Baltic Journal of Economic Studies, 5 (2), 124-130. doi: http://doi.org/10.30525/2256-0742/2019-5-2-124-130

[9] Gross domestic product (1990-2017). Available at: http://www.ukrstat.gov.ua/operativ/operativ2005/vvp/vvp_ric/vvp_e.htm

[10] Tax revenue. Available at: http://cost.ua/en/budget/revenue/\#1

[11] Pension Fund. Available at: http://cost.ua/en/budget/revenue/pension/

[12] Consumer price indices for goods and services in 2002-2018 (year to previous year). Available at: http://www.ukrstat.gov.ua/ operativ/operativ2008/ct/cn_rik/icsR/iscR_e/isc_tp_rik_e.htm

[13] Paying Taxes Methodology. Available at: https:/www.doingbusiness.org/en/methodology/paying-taxes

[14] Paying Taxes 2019. Available at: https://www.pwc.com/gx/en/paying-taxes/pdf/pwc-paying-taxes-2019.pdf

[15] Paying Taxes. Available at: http://www.doingbusiness.org/en/data/exploretopics/paying-taxes 